\title{
Guidelines for the diagnosis and treatment of coronavirus disease 2019 (COVID-19) in China
}

\author{
Youyao Xu ${ }^{1, \S}$, Yizhen Chen ${ }^{1, \S}$, Xiaoyan Tang ${ }^{2, *}$ \\ ${ }^{1}$ Zhejiang Chinese Medical University, Hangzhou, Zhejiang, China; \\ ${ }^{2}$ Hangzhou Medical College, Hangzhou, Zhejiang, China.
}

\begin{abstract}
With the deepening of the understanding and research in coronavirus disease 2019 (COVID-19), the diagnosis and treatment of COVID-19 have been constantly updated and improved. In China, since the implementation of "Guidelines for the Diagnosis and Treatment of COVID-19 (1 $1^{\text {st }}$ Trial Version)" on Jan. 15, 2020, $2^{\text {nd }}$ to $7^{\text {th }}$ versions (including revision of $5^{\text {th }}$ version) was updated from Jan. 18, Jan. 22, Jan. 27, Feb. 4, Feb. 8, Feb. 18 and Mar. 3, respectively. Versions updated subsequently provide more detailed information in many ways than the $1^{\text {st }}$ and $2^{\text {nd }}$ versions, so this paper will introduce the development of the main contents of the $3^{\text {rd }}$ to $7^{\text {th }}$ versions of COVID-19 guidelines in China, which hopes to provide help for clinical medical staff in other countries fighting with this disease.
\end{abstract}

Keywords: COVID-19, diagnosis and treatment, guideline

\section{Introduction}

Since Dec. 8, 2019, some patients presented with pneumonia of unknown origin in Wuhan, Hubei, China. The disease is confirmed as a novel coronavirus infection (1) according to the sequencing results and named COVID-19 (2). The epidemic has been under control in China recently because of active prevention and control of various forces across the country (3). Little is known about COVID-19 because it is a totally new virus (4). With the deepening of understanding and research in COVID-19, diagnosis and treatment of COVID-19 have been constantly updated and improved in China. Since the implementation of "Guidelines for the Diagnosis and Treatment of COVID-19 ( $\left(1^{\text {st }}\right.$ Trial Version)" on Jan. 15, $2020,2^{\text {nd }}$ to $7^{\text {th }}$ versions (including revision of $5^{\text {th }}$ version) was updated on Jan. 18, Jan. 22 (5), Jan. 27 (6), Feb. 4 (7), Feb. 8 (8), Feb. 18 (9) and Mar. 3 (10), respectively. Versions updated subsequently provide more detailed information in many ways than the $1^{\text {st }}$ and $2^{\text {nd }}$ versions, so this paper will introduce the development of the main contents of the $3^{\text {rd }}$ to $7^{\text {th }}$ versions, which hopes to provide help for clinical medical workers.

\section{Main frame, etiology, epidemiology, and pathology}

The comparison of main frame in the $3^{\text {rd }}$ to $7^{\text {th }}$ versions are listed in Table 1. Compared with the $3^{\text {rd }}$ version, the $4^{\text {th }}$ version clarified the epidemiological characteristics and the timeliness of case detection and reporting, added clinical typing, improved the efficiency of diagnosis and treatment. The $5^{\text {th }}$ and $6^{\text {th }}$ versions updated the epidemiological characteristics, classification, and diagnosis and treatment methods again. $7^{\text {th }}$ version added pathology and clinical warning indications of severe and critical cases.

The content of the $3^{\text {rd }}$ version on etiological characteristics is mainly based on study of coronaviruses that have been found previously, its common characteristics are proposed, and it is pointed out that the coronaviruses of unexplained pneumonia in Wuhan belongs to $\beta$-corona virus. The $4^{\text {th }}$ version began to list the virology characteristics of COVID-19 separately, with a little bit of difference comparing SARS-CoV and MERS-CoV in genetic traits. At the same time, the homology of this virus and the bat-SL-CoVZC45 was more than $85 \%$. COVID-19 can be found in human respiratory epithelial cells in about 96 hours, while it takes about 6 days to isolate and culture in Vero E6 and Huh-7 cell lines. COVID-19 is sensitive to ultraviolet light and heat. Most disinfectants can inactivate the virus effectively except for chlorhexidine. So hand disinfectants containing chlorhexidine should be avoided.

Epidemiology includes infectious agent, transmission and susceptible population. With the advance of epidemiological investigation, the epidemiological characteristics have been constantly updated (Table 1). The $7^{\text {th }}$ version indicates that the main infectious agent is patient infected with COVID-19, asymptomatic infections can also be infectious agents. Respiratory droplets and contact transmission accounts for most of the transmission, the environment polluted by feces 
Table 1. Comparison of main frame, epidemiological characteristics in the $3^{\text {rd }}$ to $7^{\text {th }}$ versions of Guidelines for the Diagnosis and Treatment of COVID-19 in China

\begin{tabular}{|c|c|c|c|c|}
\hline Version & Main frame & Infectious agent & Transmission & Susceptible population \\
\hline $3^{\text {rd }}$ & $\begin{array}{l}\text { etiology, clinical characteristics, case definition, } \\
\text { differential diagnosis, case finding and reporting, } \\
\text { treatment, criteria for discontinuation and discharge, } \\
\text { transfer principles, nosocomial infection control }\end{array}$ & N/A & N/A & N/A \\
\hline $4^{\text {th }}$ & $\begin{array}{l}\text { etiology, epidemiology, clinical characteristics, } \\
\text { diagnostic criteria, classification, differential diagnosis, } \\
\text { case finding and reporting, treatment, criteria for } \\
\text { discontinuation and discharge, transfer principles, } \\
\text { nosocomial infection control }\end{array}$ & $\begin{array}{l}\text { patient infected with } \\
\text { COVID-19 }\end{array}$ & $\begin{array}{l}\text { respiratory droplet } \\
\text { and contact } \\
\text { transmission }\end{array}$ & $\begin{array}{l}\text { the crowd is generally } \\
\text { susceptible }\end{array}$ \\
\hline $5^{\text {th }}$ & same as above & $\begin{array}{l}\text { addition: asymptomatic } \\
\text { infections can also be } \\
\text { infectious agent }\end{array}$ & same as above & same as above \\
\hline $6^{\text {th }}$ & same as above & same as above & $\begin{array}{l}\text { addition: aerosols } \\
\text { transmission }\end{array}$ & same as above \\
\hline $7^{\text {th }}$ & $\begin{array}{l}\text { etiology, epidemiology, pathology, clinical } \\
\text { characteristics, diagnostic criteria, classification, } \\
\text { clinical warning indicates severe and critical cases, } \\
\text { differential diagnosis, case finding and reporting, } \\
\text { treatment, criteria for discontinuation and discharge, } \\
\text { transfer principles, nosocomial infection control }\end{array}$ & same as above & $\begin{array}{l}\text { addition: transmission } \\
\text { by contact with feces } \\
\text { and urine }\end{array}$ & same as above \\
\hline
\end{tabular}

and urine might cause aerosols or contact transmission. It is also possible to transmit by aerosol when exposed to high concentrations of aerosols for a long time in a relatively closed environment. At last, the crowd is generally susceptible for this virus.

Based on the currently limited results of autopsy and histopathological specimens, the $7^{\text {th }}$ version adds to the pathologic presentation of the disease. The lung, spleen, hilar lymph nodes and bone marrow, heart and blood vessels, liver and gallbladder, kidney and other organs were described in detail from macroscopic and microscopic perspectives. It is emphasized that this disease mainly causes lung and immune system damage, and most of the other organs have secondary damage. It is worth noting that microthrombus can be seen in most organs. Combined with clinical manifestations and lab results, which suggests the possibility of vascular endothelial damage. More attention should be paid in clinical management for medical staff.

\section{Clinical characteristics}

For clinical manifestations, the $3^{\text {rd }}$ version pointed out that "fever, fatigue, dry cough as the main manifestations", while the rare symptoms, serious complications and special manifestations of patients were described. The $4^{\text {th }}$ version added "The incubation period is generally 3-7 days, up to 14 days", clinical symptoms increased "diarrhea". It also pointed out that some patients "no pneumonia performance", "children with relatively mild symptoms", "deaths are more common in the elderly and those with chronic underlying diseases".
The $5^{\text {th }}$ version further clarified that the incubation period range is "1-14 days", added "sore throat" performance. The $6^{\text {th }}$ version added "myalgia" performance, and severe cases may appear "multiple organ failure".

For lab results, the $3^{\text {rd }}$ version mainly described the changes in peripheral blood, biochemical and inflammatory indicators. The $4^{\text {th }}$ version proposed the etiological examination method for the first time, "the nucleic acid can be detected in throat wipes, sputum, lower respiratory tract secretions, blood and other samples". The $5^{\text {th }}$ version added "feces" to the pathogen detection samples. The $6^{\text {th }}$ version indicated that "severe and critical patients often have elevated inflammatory factors", and "it is recommended to retain sputum as much as possible and implement lower respiratory tract secretions from patients with endotracheal intubation". The $7^{\text {th }}$ version further increased the content of pathogen examination, added "NGS method" used for nucleic acid detection of samples, and introduced serological (IgM, $\mathrm{IgG}$ ) examination of pathogens for the first time.

For chest CT scan, there was no change in this area. Update of Clinical characteristics in the $3^{\text {rd }}$ to $7^{\text {th }}$ version is shown in Table 2. The clinical features of the $7^{\text {th }}$ version are described below.

\section{Clinical manifestations}

The incubation period is 1-14 days, most of which is 3-7 days. These patients' clinical manifestations were mainly fever, fatigue and dry cough. At the same time, rare symptoms, severe complications and special manifestations were described, such as stuffy nose, 
Table 2. Comparison of clinical characteristics, diagnosis criteria in the $3^{\text {rd }}$ to $7^{\text {th }}$ versions of Guidelines for the Diagnosis and Treatment of COVID-19 in China

\begin{tabular}{|c|c|c|c|c|c|}
\hline Version & Clinical manifestations & Lab results & Chest CT scan & Suspected cases & Confirmed cases \\
\hline $3^{\text {rd }}$ & $\begin{array}{l}\text { the main clinical } \\
\text { manifestations include } \\
\text { fever, fatigue and dry } \\
\text { cough }\end{array}$ & $\begin{array}{l}\text { peripheral blood: leukocyte counts } \\
\text { decreased or normal, lymphopenia. } \\
\text { biochemical test: peptase, creatase } \\
\text { and myoglobin increased. } \\
\text { inflammatory marker: C-reactive } \\
\text { protein and blood sedimentation } \\
\text { increased, procalcitonin common }\end{array}$ & $\begin{array}{l}\text { multifocal patchy } \\
\text { shadows or ground } \\
\text { glass opacities }\end{array}$ & N/A ${ }^{*}$ & N/A ${ }^{*}$ \\
\hline $4^{\text {th }}$ & same as above & $\begin{array}{l}\text { addition: the virus nucleic acid } \\
\text { could be detected in samples } \\
\text { of throat swab, sputum, lower } \\
\text { respiratory tract secretion, blood }\end{array}$ & same as above & $\begin{array}{l}\text { Any one in } \\
\text { epidemiological history+ } \\
\text { any two in clinical } \\
\text { manifestations }\end{array}$ & $\begin{array}{l}\text { Suspected cases }+ \\
\text { one of the etiological } \\
\text { evidence }\end{array}$ \\
\hline $5^{\text {th }}$ & same as above & $\begin{array}{l}\text { addition: feces can detect the virus } \\
\text { nucleic acid }\end{array}$ & same as above & $\begin{array}{l}\text { Any one in } \\
\text { epidemiological history+ } \\
\text { any two in clinical } \\
\text { manifestations OR } \\
\text { all entries in clinical } \\
\text { manifestations }\end{array}$ & same as above \\
\hline $6^{\text {th }}$ & same as above & same as above & same as above & same as above & same as above \\
\hline $7^{\text {th }}$ & same as above & $\begin{array}{l}\text { addition: NGS and serological } \\
\text { examination of pathogens (IgM, } \\
\text { IgG) can detect the virus nucleic } \\
\text { acid. }\end{array}$ & same as above & same as above & $\begin{array}{l}\text { Suspected cases }+ \text { one } \\
\text { of the etiological }{ }^{* *} \text { or } \\
\text { serology evidence }^{* * * *}\end{array}$ \\
\hline
\end{tabular}

"In the $3^{\text {rd }}$ version, patients were divided into suspected cases, confirmed cases, severe cases and critical cases, and the subsequent versions were only divided into suspected cases and confirmed cases. ${ }^{* *}$ RT-PCR or Next Generation Sequencing technology (NGS). ${ }^{* * *}$ Pathogens (IgM, IgG)

nasal discharge, pharyngalgia, myalgia, diarrhea, etc. However, symptoms in children and neonates can be uncharacteristic. Notably particularly, symptoms are relatively mild in children's case, and the elderly and those with chronic underlying diseases have poor prognosis.

\section{Lab results}

The lab results were divided into two categories: general examination, pathogenic and serological examination. The former includes peripheral blood, biochemical tests and inflammatory markers. In the early stage of the disease, leukocyte counts decreased or normal and lymphopenia in peripheral blood. Part of patients were increased in peptase, lactate dehydrogenase (LDH), creatase and myoglobin. Most patients have a normal level of procalcitonin with significantly increased levels of C-reactive protein. D-dimer levels are significantly elevated in severe cases, which is a potential risk factor for poor prognosis. Peripheral blood lymphocytes were progressively decreased. Severe and critical cases often have elevated inflammatory factors. The latter includes etiological and serological examination. For etiological examination, COVID-19 nucleic acids can be detected in specimens such as nasopharyngeal swabs, sputum and other lower respiratory secretions, blood, and feces using RT-PCR or/and next generation sequencing technology (NGS). It is more accurate to test lower respiratory tract specimens (sputum or airway aspirates). Submit samples as soon as possible after collection. For serological examination, IgM antibody is detectable 3 to 5 days after symptom onset and specific IgG antibody titer in the recovery phase 4 times higher than that in the acute phase.

\section{Chest CT scan}

Chest CT scan indicates multifocal patchy shadows or ground glass opacities. An experienced radiologist or clinician can make a diagnosis of a suspected case based on the imaging features of the lung, but attention should be paid to other viral pneumonia.

\section{Diagnostic criteria}

In the $3^{\text {rd }}$ version, patients were divided into suspected cases, confirmed cases, severe cases and critical cases, and the subsequent versions were only divided into suspected cases and confirmed cases. A total of four versions were included in this study (Table 2). The $4^{\text {th }}$ version adjusted to "Wuhan or other areas with continuous transmission of local cases". The $5^{\text {th }}$ version to $7^{\text {th }}$ versions were changed to "Wuhan and surrounding areas, or other communities with case reports". From $4^{\text {th }}$ to $7^{\text {th }}$ edition, the diagnostic criteria was essentially unchanged. It's not hard to find that the nucleic acid of SARS-CoV-2 is the gold standard for the diagnosis 
of COVID-19. However, considering the possibility of false negatives in nucleic acid detection, suspected cases characteristic manifestations in CT scans can be treated as confirmed cases even if the nucleic acid test is negative. The diagnostic criteria of the $7^{\text {th }}$ version are described below.

\section{Suspected cases}

Any one in epidemiological history+ any two in clinical manifestations or all entries in clinical manifestations:

Epidemiological history: $i$ ) The history of travelling or residence in Hubei province, including areas around Hubei, or other communities where cases have been reported occurred within the previous 14 days; $i$ ) Contact with patients with fever or respiratory symptoms who come from Hubei province, including areas around Hubei, or other communities where cases have been reported that occurred within the previous 14 days; iii) History of contact with patients who have been infected with COVID-19; iv) Clustering onset.

Clinical manifestations: $i$ ) Respiratory tract symptoms and/or fever; ii) Consistent with the pulmonary imaging characteristics of this disease; iii) Leukocyte counts decreased or normal and lymphopenia in peripheral blood.

\section{Confirmed cases}

Suspected cases + one of the etiological evidence or serology evidence: $i$ ) COVID-19 nucleic acid positive with real-time fluorescence RT-PCR; ii) Results of viral gene sequencing are highly homologous with COVID-19; iii) Both COVID-19 specific IgM and IgG antibody were positive; Specific IgG antibody titer in the recovery phase 4 times higher than that in the acute phase.

\section{Clinical classification}

The $3^{\text {rd }}$ version did not specifically propose the concept of clinical classification, and the diagnostic criteria for severe type and critical type were proposed in the disease diagnostic criteria. The $4^{\text {th }}$ version was divided into moderate, severe, and critical type. The $5^{\text {th }}$ began to add the clinical classification of "mild type". The $7^{\text {th }}$ version was divided into mild, moderate, severe, and critical type in clinical classification and adds diagnostic criteria for severe type in children because the classification of disease types is conducive to the development of case management and treatment (Table 3), the details are as follows.

Mild type: The clinical symptoms are mild and no pneumonia manifestations can be found in imaging.

Moderate type: Patients have symptoms such as fever and respiratory tract symptoms, etc. At the same time, pneumonia manifestations can be seen in imaging.

Severe type: Adults who meet any of the following criteria: respiratory rate (RR) 30 breaths/min; oxygen saturation $\leq 93 \%$ in a resting state; arterial partial pressure of oxygen $\left(\mathrm{PaO}_{2}\right)$ /oxygen concentration $\left(\mathrm{FiO}_{2}\right)$ $\leq 300 \mathrm{mmHg}$. Patients with $>50 \%$ lesions progression

Table 3. Comparison of clinical classification in the $3^{\text {rd }}$ to $7^{\text {th }}$ versions of Guidelines for the Diagnosis and Treatment of COVID-19 in China

\begin{tabular}{|c|c|c|c|c|}
\hline Version & Mild type & Moderate type & Severe type & Critical type \\
\hline $3^{\text {rd }}$ & N/A & N/A & $\begin{array}{l}\text { Adults who meet any of the following } \\
\text { criteria: respiratory rate } 30 \text { breaths } / \mathrm{min} \text {; } \\
\text { oxygen saturation } \leq 93 \% \text { at a rest state; } \\
\text { arterial partial pressure of oxygen }\left(\mathrm{PaO}_{2}\right) / \\
\text { oxygen concentration }\left(\mathrm{FiO}_{2}\right) \leq 300 \mathrm{mmHg} \text {. } \\
\text { patients with }>50 \% \text { lesions progression } \\
\text { within } 48 \text { hours in lung imaging }\end{array}$ & $\begin{array}{l}\text { Meeting any of the following } \\
\text { criteria: occurrence of } \\
\text { respiratory failure requiring } \\
\text { mechanical ventilation; } \\
\text { presence of shock; other } \\
\text { organ failure that requires } \\
\text { monitoring and treatment in } \\
\text { the ICU }\end{array}$ \\
\hline $4^{\text {th }}$ & N/A & $\begin{array}{l}\text { patients have symptoms } \\
\text { such as fever and } \\
\text { respiratory tract symptoms, } \\
\text { pneumonia manifestations } \\
\text { can be seen in imaging }\end{array}$ & $\begin{array}{l}\text { deletion: patients with }>50 \% \text { lesions } \\
\text { progression within } 48 \text { hours in lung imaging }\end{array}$ & same as above \\
\hline $5^{\text {th }}$ & $\begin{array}{l}\text { the clinical symptoms are } \\
\text { mild and no pneumonia } \\
\text { manifestations can be } \\
\text { found in imaging }\end{array}$ & same as above & same as above & same as above \\
\hline $6^{\text {th }}$ & same as above & same as above & $\begin{array}{l}\text { addition: Patients with }>50 \% \text { lesions } \\
\text { progression within } 24 \text { to } 48 \text { hours in lung } \\
\text { imaging should be treated as severe cases }\end{array}$ & same as above \\
\hline $7^{\text {th }}$ & same as above & same as above & $\begin{array}{l}\text { addition: diagnostic criteria for severe type } \\
\text { in children }\end{array}$ & same as above \\
\hline
\end{tabular}


within 24 to 48 hours in lung imaging should be treated as severe cases.

Children who meet any of the following criteria: dyspnea except for crying ( $<2$ months, RR 60 breaths/ min; 2-12 months, RR 50 breaths/min; $1-5$ years, RR 40 breaths/min; > 5 years, RR 30 breaths/min ); oxygen saturation $\leq 92 \%$ in a resting state; ventilator support (grunting, movement of alae nasi, three concave sign), cyanosis, intermittent dyspnea; lethargy or fainting; refusal to eat or poor feeding, dehydration.

Critical type: Meeting any of the following criteria: occurrence of respiratory failure requiring mechanical ventilation; presence of shock; other organ failure that requires monitoring and treatment in the ICU.

\section{Clinical warning indication of severe and critical cases}

The $7^{\text {th }}$ version added clinical warning indicators. Through the monitoring of these clinical warning indicators, the treatment of intervention can be carried out early. So as to greatly reduce the transformation of mild type to severe type and severe type to critical type, and greatly improve the cure rate. This indication serves as a red flag that the disease may worsen, which helps medical staff make accurate judgments.

Adult: $i$ ) Peripheral blood lymphocytes progressively decreased; ii) Peripheral inflammatory factors such as IL-6 and CRP progressively increased; iii) Lactic acid is progressively increased; $i v$ ) Intrapulmonary lesions progress rapidly in a short period of time.

Children: i) RR increased; ii) Poor mental response, lethargy; iii) Lactic acid is progressively increased; $i v)$ Imaging findings show bilateral or multilobular infiltration, pleural effusion, or rapid progression of short-term lesions; v) Infants under 3 months of age or underlying diseases, immune deficiency or hypoxia.

\section{Treatment}

The contents of treatment in the $3^{\text {rd }}$ to $7^{\text {th }}$ versions are divided into four parts, including: $i$ ) determine the treatment site according to the severity of the disease; ii) general treatment (including general supportive treatment, monitoring related indicators, antiviral treatment, etc.); iii) treatment of severe and critical cases (including respiratory support, circulatory support, etc.); iv) traditional Chinese medicine treatment. The treatment regimen needs to be constantly updated (Table 4), the treatment of the $7^{\text {th }}$ version are described below. What's more, the drugs recommended in the $7^{\text {th }}$ version have some theoretical basis in treatment. However, the above drugs still lack the exact clinical data in COVID-19 patients, and the specific efficacy needs to be confirmed by clinical studies. At the same time, medical staff should pay attention to the safety of drugs.

\section{Treatment sites}

Suspected cases should be in single room, confirmed cases can be placed in multiple room. Critical type should be admitted to ICU as soon as possible.

\section{General treatment}

i), General support for treatment. ii), Monitoring related indicators. iii), Oxygen therapy in time and Hydrogen-

Table 4. Comparison of treatment in the $3^{\text {rd }}$ to $7^{\text {th }}$ versions of Guidelines for the Diagnosis and Treatment of COVID-19 in China

\begin{tabular}{|c|c|c|c|c|}
\hline Version & Treatment sites & Antiviral treatment & Treatment of severe and critical cases & Traditional Chinese medicine treatment \\
\hline $3^{\text {rd }}$ & $\begin{array}{l}\text { suspected cases in } \\
\text { single room, confirmed } \\
\text { cases in multiple room. } \\
\text { critical type should } \\
\text { be admitted to ICU as } \\
\text { soon as possible }\end{array}$ & $\begin{array}{l}\alpha \text {-interferon and } \\
\text { lopinavir/ritonavir }\end{array}$ & $\begin{array}{l}\text { therapeutic principles, respiratory } \\
\text { support and support of the circulation } \\
\text { addition: glucocorticoids and plasma } \\
\text { transfusion; strengthen psychological } \\
\text { counseling }\end{array}$ & $\begin{array}{l}\text { Different prescriptions are recommended } \\
\text { according to the medical observation } \\
\text { stage, clinical treatment stage (initial } \\
\text { stage, middle stage, severe stage, } \\
\text { recovery stage) }\end{array}$ \\
\hline $4^{\text {th }}$ & same as above & same as above & $\begin{array}{l}\text { addition: respiratory support were } \\
\text { divided into four parts: oxygen therapy, } \\
\text { noninvasive respiratory support, } \\
\text { endotracheal intubation respiratory } \\
\text { support and ECMO; plasma purification } \\
\text { therapy }\end{array}$ & same as above \\
\hline $5^{\text {th }}$ & same as above & same as above & same as above & same as above \\
\hline $6^{\text {th }}$ & same as above & $\begin{array}{l}\text { addition: ribavirin, } \\
\text { chloroquine } \\
\text { phosphate and } \\
\text { arbidol }\end{array}$ & addition: CRRT, immunoglobulin & $\begin{array}{l}\text { clinical treatment period is reclassified } \\
\text { as light, ordinary, severe, critical and } \\
\text { recovery period }\end{array}$ \\
\hline $7^{\text {th }}$ & same as above & same as above & & same as above \\
\hline
\end{tabular}


oxygen mixed inhalation gas $\left(\mathrm{H}_{2} / \mathrm{O}_{2}: 66.6 \% / 33.3 \%\right)$ can be used if conditions permit. $i v$ ), Antiviral treatment: Alternative antiviral drugs: $\alpha$-interferon, lopinavir/ ritonavir, ribavirin, chloroquine phosphate, arbidol. Medical staff should pay attention to adverse reactions, contraindications and interactions with other drugs. At the same time, simultaneous use of three or more antiviral drugs is not recommended, discontinuation of the use of drugs in the presence of intolerable toxic and side effects. Antiviral treatment of maternal patients should consider the number of weeks of gestation and whether to terminate pregnancy before treatment, and informed. v), Antimicrobial therapy: Medical staff should avoid the blind or inappropriate use of antibiotics in the diagnosis and treatment process.

\section{Treatment of severe and critical cases}

i), Therapeutic principles: The treatment of primary diseases should also take the basic diseases into account. ii) Respiratory support: Oxygen therapy, high-flow nasal cannula oxygen therapy (HFNC) and noninvasive positive pressure ventilation (NIPPV), invasive positive pressure ventilation (IPPV) and rescue therapy are selected according to patient's pulmonary function. iii) Support of the circulation. iv) Continuous renal replacement therapy (CRRT). v) Plasma transfusion: Plasma from recovered persons is used to treat patients with rapid progression, severe or critical cases are suggested. vi) Plasma purification therapy: This method can remove inflammatory factors and reduce loss of inflammatory response of the body. vii) Immunoglobulin: Tocilizumab can be used in patients with extensive bilateral lung lesions and severe cases, and the laboratory detects elevated IL-6 levels. viii) Other treatment: For patients with rapid disease progression, glucocorticoids can be used for a short period of time. Gamma globulin may be considered in children with severe and critical cases. In addition, pregnant women with severe or critical cases should terminate their pregnancy actively, emphasizing caesarian as the first choice. At last, medical staff should strengthen psychological counseling because patients often have anxiety and fear.

\section{Traditional Chinese medicine treatment}

Traditional Chinese medicine treatment should be based on different conditions, local climate characteristics, and different physical conditions, and referred to the guidelines for dialectical treatment.

\section{Discharge standards and follow-up plan}

From $3^{\text {rd }}$ to $7^{\text {th }}$ edition, the discharge standards are essentially unchanged. For follow-up plan, it was added in the last two editions, the details are as follows. After the patient is discharged from the hospital, there is a risk of infection with other pathogens and COVID-19 due to the immunocompromised body during the recovery period. Follow-up plan has a good promoting effect on the health of discharged patients.

Discharge standards: $i$ ) Body temperature remains normal for at least 3 days; ii) Respiratory symptoms are significantly improved; iii) Nucleic acid is tested negative for respiratory tract pathogen twice consecutively; $i v$ ) Lung imaging shows obvious improvement in lesions.

Follow-up plan: i) Designated hospitals should make good contact with the primary medical institutions where patients live and share medical records; $i$ ) Patients must continue two weeks of isolation after discharge. Patients and their family members must wear masks and wash hands frequently. Patients should live in an area with frequent ventilation and is disinfection independent; iii) The outpatient follow-up will be carried out 2 weeks and 1 month after discharge.

\section{Conclusion}

Guided by the research of etiology, diagnostic classification criteria and treatment specifications, each version updates the diagnosis and treatment plan, especially the $7^{\text {th }}$ version. It provided more comprehensive, reasonable, clearer and efficient diagnosis and treatment guidance for clinical medical staff. COVID-19 has a very high ability to infect, however, the mortality of patients infected with COVID-19 is not as high as those infected with MERS or SARS. COVID-19 is a totally new virus without specific antibody or anti-COVID-19 drug, so cut off of transmission routes and isolation of sources of infection are the most effective methods to stop the spread. For patients with severe or fatal organ dysfunction, effective organ support and immune-enhancement methods are crucial for treatment.

\section{References}

1. Zhu N, Zhang D, Wang W, et al. A novel coronavirus from patients with pneumonia in China, 2019. N Engl J Med. 2020; 382:727-733.

2. World Health Organization. Coronavirus disease (COVID-2019) situation report. https://www.who.int/ emergencies/diseases/novel-coronavirus-2019/situationreports/ (accessed March 22, 2020).

3. Chen N, Zhou M, Dong X, Qu J, Gong F, Han Y, Qiu Y, Wang J, Liu Y, Wei Y, Xia J1, Yu T, Zhang X, Zhang L. Epidemiological and clinical characteristics of 99 cases of 2019 novel coronavirus pneumonia in Wuhan, China: a descriptive study. Lancet. 2020; 395: 507-513.

4. Wang D, Hu B, Hu C, Zhu F, Liu X, Zhang J, Wang B, Xiang H, Cheng Z, Xiong Y, Zhao Y, Li Y, Wang $\mathrm{X}$, Peng Z. Clinical characteristics of 138 hospitalized patients with 2019 novel coronavirus-infected pneumonia in Wuhan, China. JAMA. 2020; doi: 10.1001/ jama.2020.1585.

5. National Health Commission of the People's Republic of China. Guidelines for the diagnosis and treatment of 
COVID-19 ( $3^{\text {rd }}$ Trial Version) http://www.nhc.gov.cn/xcs/ zhengcwj/202001/f492c9153ea9437bb587ce2ffcbeel fa/fi les/39e7578d85964dbe81117736dd789d8f.pdf (accessed March 22, 2020) (in Chinese)

6. National Health Commission of the People's Republic of China. Guidelines for the diagnosis and treatment of Corona Virus Disease-2019 infection by the National Health Commission (4 ${ }^{\text {th }}$ Trial Version) http://www.nhc. gov.cn/yzygj/s7653p/202001/4294563ed35b43209b31739 bd0785e67/files/7a9309111267475a99d4306962c8bf78. $p d f$ (accessed March 22, 2020) (in Chinese)

7. National Health Commission of the People's Republic of China. Guidelines for the diagnosis and treatment of Corona Virus Disease-2019 infection by the National Health Commission ( $5^{\text {th }}$ Trial Version) http://www.nhc. gov.cn/yzygj/s7653p/202002/3b09b894ac9b4204a79db5 b8912d4440/files/7260301a393845fc87fcf6dd52965ecb. $p d f$ (accessed March 22, 2020) (in Chinese)

8. National Health Commission of the People's Republic of China. Guidelines for the diagnosis and treatment of Corona Virus Disease-2019 infection by the National Health Commission (Revision of $5^{\text {th }}$ Trial Version) http:// www.nhc.gov.cn/yzygj/s7653p/202002/d4b895337e19445 f8d728fcafle3e13a/files/ab6bec7f93e64e 7f998d8029912 03cd6.pdf (accessed March 22, 2020) (in Chinese)

9. National Health Commission of the People's Republic of China. Guidelines for the diagnosis and treatment of Corona Virus Disease-2019 infection by the National Health Commission ( $6^{\text {th }}$ Trial Version) http://www.nhc. gov.cn/yzygj/s7653p/202002/8334a8326dd94d329df351d 7da8aefc2/files/b218cfeb1bc54639af227f922bf6b817.pdf (accessed March 22, 2020) (in Chinese)

10. National Health Commission of the People's Republic of China. Guidelines for the diagnosis and treatment of Corona Virus Disease-2019 infection by the National Health Commission ( $7^{\text {th }}$ Trial Version) http://www.nhc. gov.cn/yzygj/s7653p/202003/46c9294a7dfe4cef80dc7f5 912eb1989/files/ce3e6945832a438eaae415350a8ce964. $p d f$ (accessed March 22, 2020) (in Chinese)

Received March 26, 2020; Revised April 15, 2020; Accepted April 21, 2020.

Released online in J-STAGE as advance publication April 26, 2020.

${ }^{\S}$ These authors contributed equally to this work.

*Address correspondence to:

Xiaoyan Tang, Hangzhou Medical College, No. 481 of Binwen Road, Hangzhou 310053, China.

E-mail: tangxiaoyan310@126.com 